\title{
School Culture as a Predictor of Teachers' Alienation at Schools
}

\author{
Research Article
}

\section{Mithat KORUMAZ¹, Gulenay Nagihan KILIC ${ }^{2}$, Ibrahim KOCABAS ${ }^{3}$}

${ }^{1}$ Yildiz Technical University, Faculty of Education, Department of Educational Science, Istanbul, Turkey, ORCID: 0000-0003-1800-7633

2 Yildiz Technical University, Department of Educational Science PhD Student, Istanbul, Turkey, ORCID: 0000-0002-6280-8537

${ }_{3}^{3}$ Yildiz Technical University, Faculty of Education, Department of Educational Science, Istanbul, Turkey, ORCID: 0000-0002-3540-2427

To cite this article: Korumaz, M., Kilic, G. N., \& Kocabas, I. (2020). School Culture as a Predictor of Teachers' Alienation at Schools, International Online Journal of Educational Sciences, 12(3), 42-58.

\begin{abstract}
ARTICLE INFO
ABSTRACT

Article History:

Received: 02.11.2019

Available online:

19.06.2020

This research aims to reveal the relationship between teachers' perceptions of alienation at schools and in terms of weakness, meaninglessness, isolation and alienation at schools, their perceptions of school culture with support, success, bureaucratic and task culture. The research employed correlational design which is one of the quantitative research approaches. The sample of the research consists of 481 teachers determined by random sampling method. Research data were obtained by using the 'Work Alienation Scale' and 'School Culture Scale'. While analyzing the data, linear correlation and multiple regression analyzes were used. The data obtained as a result of the research were examined, it was concluded that there was a significant relationship between teachers' alienation levels and school culture. Success, support and duty culture, which are the sub-dimensions of school culture, predicts the level of weakness, meaninglessness and isolation, which are the subdimensions of alienation at school. Bureaucratic culture, which is the sub-dimension of school culture, predicts the level of weakness, meaninglessness and isolation of alienation at school. According to the results of the research, it is possible to state that strengthening the school culture will decrease the alienation levels of teachers at schools.
\end{abstract}

(C) 2020 IOJES. All rights reserved

Keywords:

School culture, alienation, teachers, prediction, regression

\section{Introduction}

In a context in which teachers are employed as civil servants and their job security is guaranteed by the state, they may not be considered to resign. Despite this, in Turkish context between the years 2012 to 2018, 107.9083 teachers resigned for various reasons (MoNE, 2018). Resignation of teachers occurs in a similar manner in other communities. For example, according to the data of the U.S. Department of Education, 7.4\% of teachers left their jobs between 1999-2001. It is possible to say that the social cost of these resignation rates

\footnotetext{
${ }^{1}$ Corresponding author's address: Yildiz Technical University, Faculty of Education

Telephone: +902123834818

e-mail: mithatkorumaz@gmail.com

DOI: https://doi.org/10.15345/iojes.2020.03.004
} 
is quite high. According to the report published by Texas Center for Education Research in 2002, the total cost of the teachers leaving that year is estimated to be 329 million dollars. According to Brown and Wynn (2009) besides the economic cost of teachers' quitting, they create irreversible results and costs related to teacher quality and school climate and culture. Regarding the reasons why teachers leave school, working conditions, high performance expectations, bureaucracy, administrative problems, pressure of families (Farber, 2015), salary, working conditions and failure to meet professional development needs (Cha \& Cohen-Vogel, 2011; Hanushek, Kain, \& Rivkin, 2004; Lankford, Loeb, \& Wyckoff, 2002; Mont \& Rees, 1996). In this point of view, it is possible to state that the alienation of teachers to their work, colleagues, teaching service they offer, and their own potential is a very important variable in explaining this situation. According to Tye and O'brien (2002), the changing student behaviors, the decrease in the status of the teaching profession, financial imperfections and administrative problems make teachers insensitive to the context of education. On the other hand, as one of the reasons for teachers' alienation in schools, organizational analysis has been carried out in a wide range including the culture of the organization. As a result of these analyze, it has been observed that organizational culture and job alienation each other at schools mutually and cyclically and spread correctly from teachers to students (Ingersoll, 2001). According to Pugh and Zhao (2003) the situation of teachers' alienation at schools arises as a result of the teaching culture and administrative decisions. On the other hand, it is known that the professional attitudes of teachers created by the culture of the school are closely related to alienation to teaching (Yorulmaz, Altınkurt \& Yllmaz, 2015). As a result, it is seen that teachers' level of alienation can be affected by many organizational factors in terms of organizational behavior. However, when the studies were examined, a comprehensive study examining the relationship between school culture and teachers' alienation to work could not be reached. In this study, it is aimed to determine whether school culture is a significant predictor of teachers' level of alienation to work. School administrators, teachers, and researchers who will investigate school culture and alienation in the context of education are expected to benefit from the results of the research.

\section{Teachers' Job Alienation}

The concept of alienation is addressed in religious, philosophical, economic, social and psychological fields and various researches have been conducted on this subject. Individuals are required to interact with the environment in order to be educated and work in order to exist in the society. Individuals interacting with the environment can also be alienated from their environment. Teachers interact with other teachers and administrators. The concept of alienation has different meanings for different disciplines. Therefore, Zielinski and Hoy (1983) state that there is no definite definition of alienation. Likewise some sociologists make various definitions of alienation. The concept of alienation was first defined by Hegel (1910) as the detachment of the individual from his environment and his own self, and then the term was comprehensively handled by Marx (1844) and used to explain the effects of the capitalist labor process on workers with a socio-economic approach. According to Marx, creative activity is the basic element of human nature and this need is satisfied in the process of work, which is a meaningful activity in itself. However, in the capitalist system, the laborcapital relationship prevents the individual's creativity and turns work into a meaningless activity; For this reason, alienation is a natural part of this system and it is inevitable (Turgut \& Kalafatoğlu, 2016). Levin (1994) defines alienation as a state of social uncertainty that occurs when the individual loses its meaning. On the other hand, Frolov (1997) defines alienation as a situation that shows the process of turning human into something that dominates itself and the results of this process. According to Marshall (1999), alienation refers to individuals' divergence from each other or from a certain environment or process. Hoy (1983) defines job alienation as a reflection of the feelings of frustration regarding the employment of the person in an organization. Özler and Dirican (2014) emphasized that alienation to work means a process rather than a momentary emotion. On the other hand, Mottaz (1981) expressed alienation as a subjective emotion arising from objective working conditions. According to Keniston (1972), the alienation of the employee to the job 
refers to the inadequate relationship between the labor and the work processes of the employee. According to Elma (2003) in the context of educational organizations, as a result of alienation to work, teachers find their jobs and the developments meaningless, feeling inadequate and weak, isolate themselves from the school and their colleagues, and feeding negative attitudes towards his job. There are many reasons that affect alienation to work. For instance, the workers don't feel strong enough to decide on organizational procedures (Seeman, 1959), the job is not suitable for organizational purposes, the organization culture is not supportive, the rules of work are not clear, personal and social differences, the roles in the organization are unfamiliar. Alienation can be caused by the production procedure, working relationships, management and control patterns, and technological structures, as well as the emotional and cognitive mood of the individual in general (Özer \& Güllüce, 2019). According to Elma (2003) alienation may result from individual, social and cultural factors effecting teachers personally. In addition, alienation has social, cultural, political and organizational effects on the teachers. Therefore, there is a mutually interaction between alienation and the individual. According to Payne (1974), alienation is a multidimensional structure, it has social and organizational reasons. In general terms, alienation to work can be defined as the employee finding his job meaningless, not satisfying with the relationships s/he established at the workplace, seeing himself/herself alone, inadequate, weak, losing his/her hopes for the future and perceiving himself/herself as a simple wheel of the system.

The concept of alienation has been examined through Marxist and psychological approaches. According to the Marxist point of view, alienation is objective and seen as a natural part of the system. According to the psychological approach, alienation is a subjective condition and as a part of human life. Seeman (1959), which deals with alienation as a multi-dimensional structure with a psychological approach, has been examined in five dimensions. These are; sense of weakness, meaninglessness, normality, isolation and self-alienation. On the basis of Seeman's classification, Middleton (1963) has addressed alienation in six dimensions as weakness, normlessness, meaninglessness, social alienation, alienation from work and cultural alienation. Later Blauner (1964) stated that alienation is a subjective situation that depends on personal experience and attitudes. Mottaz (1981), on the other hand, examined alienation in three dimensions by stating that alienation's weakness, meaninglessness and self-alienation dimensions are related to work, isolation is related to organizations and employees and this dimension is unrelated to others. With a different approach, Feuer (1969) made a classification as the alienation of class society, alienation of competitive society, alienation of industrial society, alienation of human society, alienation of race and alienation of generations. Although there are different views on the dimensions of alienation, Seeman's view is widely accepted.

Weakness; according to the Marxist approach, it was defined as an objective concept as the individual's detachment from production. According to the psychological approach, Seeman defined weakness as a special concept to understand the individual's mood. Blauner (1964) stated that the dissatisfaction of control and autonomy causes the feeling of weakness. Minibaş (1993) asserted that the sense of inadequacy of the employee, the lack of management and control over the work process, frequent changes in the procedures and rules in the organization, the frequency of technology change, the inadequacy of the employee in solving the problems, the skills and competencies lagging behind the needs of the business can increase the sense of weakness. Zielinski and Hoy (1983) stated that teachers experience two types of weakness related to managerial (organizational weakness) and classroom activities (instructional weakness).

Meaninglessness; Seeman (1959) defined the concept as the individual's losing of what to believe. The fragmentation and rigidity of the work process, the inability to see the final meaning of production, the inability to grasp the whole work, the absence of creativity, initiative and uniformity, obstacles and hierarchy, inability to access information and resources, the gap between what is and what it should be may create a sense of meaninglessness in the employee (Elma, 2003). According to Terez (2010), bureaucratic climate causes sense of meaninglessness in organizations. 
Non-normative; the concept was first described by Durkheim. According to Durkheim (1893), nonnormative behaviour is a concept and situation based on social inequality. Non-normative behavior is a reflection of the lack of social order (Yüksel, 2014). The term contains the destruction of order, the destruction of the institutionalization process, the weakening of common values. It was defined by Teber (1990) in psychology as the importance that the individual adopts and uses as a measure for actions and behavior. On the other hand, Seeman (1959) defines non-normative behavior as the adoption of the behaviors approved by the society in order to achieve the goals set by the society again.

Isolation; it is defined by Elma (2003) as the avoidance of the physical environment in which the individual is found in general or in relation to other people. He stated that the reason for this avoidance was due to the psychology of the individual or the environment. According to Zielinski and Hoy (1983), in order for isolation created at the organizational level, the individual must have isolated herself/himself from those who have formal authority, individuals mentioned in the organization, other employees and colleagues in the organization.

Self-alienation; according to Başaran (1998), alienation to self means that human behaviors are not based on the value, norms, needs and wants, and behaviors do not comply with them. It is the inability of the individual to find rewarding, real satisfying activities (Tezcan, 1985). According to Seeman (1959), selfalienation in the organizational environment takes place in two directions as not being able to reveal itself at work and the lack of internal meaning of the work. According to him, the individual who becomes alien to herself/himself is not concerned with the internal factors of the task, s/he is concerned with factors such as money and security.

In general terms, alienation creates social and political effects besides individual effects. In their study, Hoy and Isherwood (1973) revealed that there is a significant relationship between alienation and formalization in schools. There is a positive relationship between hierarchical control in schools and teachers' feelings of weakness; it was also determined that as the hierarchy increased, the sense of weakness also increased. Hierarchical control affects organizational culture as it is part of bureaucracy in schools. Therefore, it is thought that there is a significant relationship between job alienation and school culture. Besides, the concept with which alienation is most related is change. Wherever there is change, there is the possibility of alienation. Alienation increases with the increase of change (Kiraz, 2011). Schools are also changing with the increasing use of technology and the active use of education. This can cause teachers to become alienated.

\section{School Culture}

The concept of culture has various meanings and is defined in different ways. Ziya Gökalp, defined the phenomenon of culture as a harmonious integrity of the social lives of a nation, which connect all the members of a society and establish solidarity among them (Yıldırım, 2013). Schein (1992) defined organizational culture as a whole of assumptions and beliefs that are effective enough to be accepted as valid, taught to new members as a correct way of perception, thinking and feeling about the problems while analyzing the problems of internal integration and external harmony. Kongar (1972) defined culture as the sum of the material and spiritual heritage that societies inherited from their history. Culture is divided into two dimensions as material and spiritual. All the tools and materials created by man are in the material culture; Again, all the meaningful, values and rules created by man are examples of spiritual culture (Güçlü, 2003). Since organizations are communities with a common culture, culture is an important concept for organizations. Organizational culture, Hoy and Miskel (2010), defined the system of orientations that hold the units together and make them different from other units and give them identity. Dinçer (1992) also defined organizational culture as the system of norms, behaviors, values, beliefs and habits that guide the behavior of people in an organization. According to Terzi (2000), its founders have great importance in the formation of organizational culture. Because it is not limited by previous ideologies, it is normal that they have a great influence on the organization 
in shaping their values and beliefs. According to Şişman (2002), organizational culture is a combination of common beliefs, values and norms in the organization. According to Aydın (2013), while culture shows the behavioral norms, assumptions and beliefs of an organization, the climate shows the perceptions of people in the organization regarding these norms, assumptions and beliefs. Organizational climate is the study of individuals' perceptions of different aspects of the internal environment. Job satisfaction of employees in organizations is often associated with organizational climate. Since job satisfaction also affects the individual's level of alienation to work, alienation to work and organizational climate are also related concepts. According to Schein (1992), the organizational culture ensures that the employees are more attached to the organization and that they make more sacrifices than they can against the organization they are a member of. From this point of view, organizational culture also acts as a control mechanism in shaping and directing employees' attitudes and behaviors (Sezgin, 2010). Therefore, since organizational culture affects individuals' attitudes towards work, it is also a concept closely related to alienation to work. When we look at the school organization, the relationship between education and culture can be mentioned, since the basic capital of educational organizations is culture (Şişman, 1995), education is a social process and the main function of education is to transfer culture, which is the product of social life, to new generations. So, education is a social phenomenon in terms of both its origin and function. The fact that the content of education varies from society to society due to the difference of the social, political and economic values that each society produces in its own geography (Doğan, 2017). The different cultures also cause the attitudes and behaviors of individuals to differ.

Although various classifications are made in the literature, five dimensions of organizational culture are widely mentioned. These are; support culture, bureaucratic culture, success culture, duty culture and power culture. Support culture is based on human relationships and trust. There is a mutual relationship and commitment among the members of the organization (Terzi, 2005). Bureaucratic culture is the culture that prevails in organizations with rational and legal structures. Bureaucratic culture is free from personal relationships, and administrators provide control over applications. It is a type of culture in which rules and standards increase. It is important to follow the standards and rules (Terzi, 2005). Success culture means a culture where doing things and achieving goals are more than rules. Individual responsibility is important. Problems are solved appropriately, and successful individuals are supported (Terzi, 2005). Task culture is the culture that organizational goals are at the forefront and dominates in business-centered organizations. Organizations work purposefully and organizational goals are more important than individual purposes.

The prevalence of various school cultures and psychological and environmental reasons may cause teachers to become alienated from work in schools that have a working environment. Negative conditions in the educational environment also prevent job satisfaction and this causes alienation. Considering that teachers are one of the most important shareholders of the school, it is of great importance to eliminate any obstacles that might harm their beliefs in their professions and to support works and practices that will help prevent alienation (İnand1, Tunç \& Rehber, 2018). Solving alienation in education; initially, it is possible by analyzing the school and its reflections in the individual's life (Yapıc1, 2004). School is an ideological institution that plays a very important role in the individual's alienation to himself and others. The alienation created by the school is a more effective, organized and deliberate structure than individual alienation with its dimension of being uniform and massive. School culture can be described as a variable that affects many forms of organizational behavior, including alienation. Determining the relationship between school culture and organizational behavior patterns as a predictive variable can be seen as important for controlling and managing these organizational behavior patterns. 


\section{Methodology}

\section{Research Design}

The research employed correlational design one of the quantitative research approaches. Research conducted in a correlational design aims to determine the presence or degree of correlation between two and more variables (Karasar, 2005). In studies conducted in accordance with the correlational design, the level of predicting one variable to another, as well as the relationship between variables, can be examined (McMillan $\&$ Schumacher, 2006). The independent variables of the research are success culture, support culture, duty culture and bureaucratic culture, which are the sub-dimensions of organizational culture. Dependent variables of the research are weakness, meaninglessness, isolation and alienation to school, which are the subdimensions of alienation to work.

\section{Sample of the Study}

The universe of the research consists of 2068 teachers working in educational institutions in Güngören district of Istanbul province (Istanbul Province Statistics, 2018). Simple random sampling method was used to determine the sample of the study. Simple random sampling is based on the possibility of each unit in the universe to take part in the research (McMillan \& Schumacher, 2006; Neuman, 2006). In order to quantitatively ensure the competence of the participants of the research to represent the universe, the formula used to determine the number of participants in random samples was used and the number of teachers included in the sample was determined accordingly (Yamane, 2006);

$\mathrm{Z}($ Standard normal variable $=\% 95$ confidence interval $)=1,96$

$\mathrm{N}($ Universe size $)=1171$

$\mathrm{P}($ Total size ratio $)=(\% 50)$ 0,5 deviation ratio (Maximum error rate)

$\mathrm{Q}=1-\mathrm{P}=0,5$

$$
\mathrm{n}=\frac{\mathrm{z}^{2} \mathrm{PQ}}{\mathrm{E}^{2}+\frac{\mathrm{Z}^{2} \mathrm{PQ}}{\mathrm{N}}}=\frac{1,96^{2} * 0,5 * 0,5}{0,05^{2}+\frac{1,96^{2} * 0,5 * 0,5}{1171}}=481
$$

Table 1. Demographics of participants

\begin{tabular}{|c|c|c|c|}
\hline Demographic Factors & & $f$ & $\%$ \\
\hline \multirow{5}{*}{ Age } & 25 years and younger & 32 & 6,7 \\
\hline & $26-35$ years & 198 & 41,2 \\
\hline & $36-45$ years & 145 & 30,1 \\
\hline & $46-55$ years & 71 & 14,8 \\
\hline & 56 years and older & 35 & 7,3 \\
\hline \multirow{3}{*}{ Career Phases } & Initiation (1-5 years) & 119 & 24,7 \\
\hline & Development (6-11 years) & 111 & 23,1 \\
\hline & Experientialism (11-15 years) & 80 & 16,6 \\
\hline
\end{tabular}




\begin{tabular}{|c|c|c|c|}
\hline & Autonomy (16-20 years) & 66 & 13,7 \\
\hline & Disenchantment (21 Years and more) & 105 & 21,8 \\
\hline \multirow{5}{*}{$\begin{array}{l}\text { Working Duration in } \\
\text { Current School }\end{array}$} & $1-5$ years & 320 & 66,5 \\
\hline & $6-10$ years & 100 & 20,8 \\
\hline & $11-15$ years & 36 & 7,5 \\
\hline & $16-20$ years & 17 & 3,5 \\
\hline & 21 years and more & 8 & 1,7 \\
\hline Total (n) & & 481 & 100 \\
\hline
\end{tabular}

As a result of the sampling calculation based on a $95 \%$ confidence interval and $0.05 \%$ error margin as suggested by Yamane (2006), it was seen that it would be sufficient to select 345 teachers. At the same time, the volunteering of the participants in the research was considered important in order to reflect the truth of the research. Totally random and voluntary, 481 teachers were willing to participate in the research. When examined according to their demographics, $32(6.7 \%)$ of the teachers in the study were under the age of 25 , $198(41.2 \%)$ were between the ages of 26-35, $145(30.1 \%)$ were between the ages of 36-45, 71 (14.8\%) are between the ages of $46-55$ and 35 are over the age of 56 . The career phases of the teachers were determined in accordance with the career phases recommended by Bakioğlu (1996). According to this, 119 (24.7\%) of the teachers participating in the study are in initiation phase, 111 (23.1\%) were the development phase, $80(16.6 \%)$ the experimentalism phase, $66(13.7 \%)$ are in autonomy phase and $105(21.8 \%)$ are in disenchantment phase. Considering the working period of teachers in their current schools, $320(66.5 \%)$ are between 1-5 years, 100 $(20.8 \%)$ are between $6-10$ years, $36(7.5 \%)$ are between the years $11-15,17(3.5 \%)$ are between $16-20$ years, and $8(1.7 \%)$ are between 21 years and more.

\section{Data Collection and Tools}

While collecting the research data, two scales were used. The first scale is the 'Work Alienation Scale' developed by Elma (2003). The work alienation scale consists of four dimensions, namely weakness, meaninglessness, isolation and alienation to school, and a total of 38 items. Cronbach Alpha coefficients for testing the reliability of the data obtained from the scale are .86 for the weakness sub-dimension, .84 for the meaningless sub-dimension, .80 for the isolation sub-dimension, .62 for the sub-dimension of being alien to school and Cronbach Alpha reliability for the data obtained from the whole scale coefficient was calculated as .79. Secondly, "School Culture Scale" developed by Terzi (2005) was used. The scale consists of four dimensions and 29 items. The dimensions of the scale are support culture, success culture, bureaucratic culture and duty culture. The Cronbach Alpha coefficients for the reliability of the data obtained from the school culture scale were calculated as .77 for the support culture, .81 for the success culture, .83 for the bureaucratic culture, .88 for the task culture. The calculated Cronbach Alpha values of the data obtained from the scales indicate that the necessary assumptions are provided for reliability. In order to test the validity of the scales to be used in the research, it was applied to 15 teachers before the main application and the structural problems of the scales were tried to be resolved. In the process of collecting the data of the research, firstly, the list of teachers in Güngören district was prepared and 350 teachers' names were determined randomly with the help of the computer program. Then, the selected teachers were contacted via e-mail and telephone, and the scales were delivered online or by hand to the teachers who accepted the research. New teachers were randomly included from the list instead of teachers who were not willing to participate in the study and continued to be randomly 
selected from the teachers list until they reached the desired number for the sample. 18 of the obtained scales could not be used for reasons such as demographic data not being marked or missing item marking.

\section{Analysis of the Data}

The data obtained as a result of the research was realized with a data analysis program used for social sciences. Primarily, Kolmogrow Smirnow test was used to test the normality of the distribution of the data. It was seen that the data obtained from the whole scale provided the assumptions of normality at the level of .05. Therefore, in order to present descriptive values, the lowest value, highest value, arithmetic mean and standard deviation scores were calculated for the purposes of the research. Then, while simple linear correlation was applied to determine the relationship between teachers' school culture and alienation levels, multiple regression analysis was used to calculate the prediction level of the independent variable of the research.

\section{Finding}

In this section, the findings reached as a result of the statistical analysis on the research problem are included. First, descriptive values of the scores obtained from work alienation and school culture scales were analyzed. Descriptive values of the data obtained from the scales are presented in Table- 2 .

Table 2. Descriptive values of work alienation and school culture scales

\begin{tabular}{|c|c|c|c|c|c|}
\hline Scale and Sub-scales & $\mathbf{n}$ & Minimum & Maximum & $\bar{X}$ & Std. \\
\hline \multicolumn{6}{|l|}{ Work Alienation } \\
\hline Weakness & 481 & 10 & 49 & 20,69 & 7,913 \\
\hline Meaninglessness & 481 & 11 & 53 & 17,50 & 7,541 \\
\hline Isolation & 481 & 10 & 43 & 17,91 & 7,077 \\
\hline Alienation to School & 481 & 7 & 34 & 23,26 & 4,902 \\
\hline \multicolumn{6}{|l|}{ School Culture } \\
\hline Support Culture & 481 & 8 & 40 & 28,90 & 6,109 \\
\hline Success Culture & 481 & 6 & 30 & 21,88 & 4,788 \\
\hline Bureaucratic Culture & 481 & 11 & 43 & 29,30 & 5,427 \\
\hline Task Culture & 481 & 6 & 30 & 24,63 & 3,560 \\
\hline
\end{tabular}

Table 2 presents the scores of 481 teachers who participated in the research on the scale of alienation from work and school culture. As a result of the analysis of the data, the lowest value taken from the entire job alienation scale is 38 and the highest value is 179 . When the sub-dimensions of the alienation scale are analyzed, the lowest value obtained in the weakness sub-dimension is 10 and the highest value is 49 . The arithmetic average of the scores obtained in the weakness dimension is 20.69 and the standard deviation of this sub-dimension is 7.913. The lowest value obtained in the meaningless sub-dimension is 11 and the highest value is 53 . The arithmetic average of the scores of this dimension is 17.50 and the standard deviation is 7.541. The lowest value obtained in the isolation sub-dimension is 10 and the highest value is 43 . The arithmetic mean of the scores of this dimension is 17.91 and the standard deviation is 7,077 . The lowest value obtained in the sub-alienation sub-dimension is 7 and the highest value is 34 . The arithmetic mean of the scores for this dimension is 23.26 and the standard deviation is 4.902 . The lowest value taken from the entire school culture 
scale is 31 and the highest value is 143 . When the sub-dimensions of the school culture scale are examined, the lowest value obtained in the support culture sub-dimension is 8 and the highest value is 40 . The arithmetic mean of the scores obtained in the support culture sub-dimension is 28.90 and the standard deviation is 6.109. The lowest value obtained in the success culture sub-dimension is 6 and the highest value is 30 . The arithmetic mean of the scores obtained in the success culture sub-dimension is 21.88 and the standard deviation is 4.788. The lowest value obtained in bureaucratic culture sub-dimension is 11 and the highest value is 43 . The arithmetic mean of the scores obtained in the bureaucratic culture sub-dimension is 29.30 and the standard deviation is 5.427. The lowest value obtained in the task culture sub-dimension is 6 and the highest value is 30. The arithmetic mean of the scores obtained in the sub-dimension of the task culture is 24.63 and the standard deviation is 3.560 .

\section{Predicting the Weakness Dimension by Sub-Dimensions of School Culture}

As a result of the multiple linear regression analysis, to show how the school culture predicts teachers' alienation to work, the sub-dimensions of school culture support, success and bureaucratic culture together have meaningful effect on weakness which is the sub-dimension of work alienation. There are meaningful relationship between the variables $\left(R=0,584, R^{2}=0.341\right),(F(4-476)=61,67, p<0,00)$. Together, these three variables explain $34 \%$ of the change in the level of alienation to work.

Table 3. Predicting the weakness dimension by sub-dimensions of school culture

\begin{tabular}{lcccccccc}
\hline Independent Variables & $\begin{array}{c}\text { Dependent } \\
\text { Variable }\end{array}$ & $\mathbf{B}$ & $\begin{array}{c}\text { Standart } \\
\text { Error }\end{array}$ & $\boldsymbol{\beta}$ & $\mathbf{t}$ & $\mathbf{p}$ & Binary $\mathbf{r}$ & Partial r \\
\hline Constant & & 37,374 & 2,445 & & 15,284 &, 000 & & \\
Support Culture & &,- 249 &, 090 &,- 192 & $-2,756$ &, 006 &,- 528 &,- 125 \\
Success Culture & Weakness &,- 625 &, 115 &,- 378 & $-5,452$ &, 000 &,- 555 &,- 242 \\
Bureaucratic Culture & &, 219 &, 057 &, 150 & 3,875 &, 000 &, 133 &, 175 \\
Task Culture & &,- 090 &, 096 &,- 041 &,- 940 &, 348 &,- 243 &,- 043 \\
\hline
\end{tabular}

$\mathrm{R}=0,584 \quad \mathrm{R}^{2}=0,341$

$\mathrm{F}(4-435)=61,67 \quad \mathrm{p}=, 000$

According to the standardized regression coefficients, the relative importance order of predictive variables on the level of weakness of alienation to work is success culture $(\beta=-0.387)$, support culture ( $\beta=$ $0.192)$, bureaucratic culture $(\beta=0.150)$. While success, support and duty culture reduces the level of weakness, bureaucratic culture increases the level of weakness. According to the results of the regression analysis, the regression equation predicting weakness is as follows:

$$
\text { Weakness }=(0,625 x \text { Success Culture })+(0,249 x \text { Support Culture })+(0,219 x B u r e a u c r a t i c ~ C u l t u r e)
$$

\section{Predicting the Meaninglessness Dimension by Sub-Dimensions of School Culture}

As a result of the multiple linear regression analysis, to show how the school culture predicts teachers' alienation to work, the sub-dimensions of school culture support, success, bureaucratic and duty culture together have meaningful effect on meaninglessness which is the sub-dimension of work alienation. There are meaningful relationship between the variables $\left(R=0,426, R^{2}=0.182\right),(F(4-476)=26,42, p<0,00)$. Together, these four variables explain $18 \%$ of the change in the level of alienation to work. 
Table 4. Predicting the meaninglessness dimension by sub-dimensions of school culture

\begin{tabular}{|c|c|c|c|c|c|c|c|c|}
\hline $\begin{array}{l}\text { Independent } \\
\text { Variables }\end{array}$ & Dependent Variable & B & $\begin{array}{c}\text { Standart } \\
\text { Error }\end{array}$ & $\beta$ & $\mathbf{t}$ & $\mathrm{p}$ & $\begin{array}{c}\text { Binary } \\
\mathbf{r}\end{array}$ & $\begin{array}{l}\text { Partial } \\
\quad \mathbf{r}\end{array}$ \\
\hline Constant & & 29,819 & 2,566 & & 11,619 & ,000 & & \\
\hline Support Culture & &,- 128 & ,095 &,- 105 & $-1,349$ & ,178 &,- 371 &,- 062 \\
\hline Success Culture & Meaninglessness &,- 408 & 120 &,- 262 & $-3,393$ & ,001 &,- 393 &,- 154 \\
\hline \multicolumn{9}{|l|}{ Bureaucratic } \\
\hline Culture & & 197 & ,059 & ,144 & 3,318 & ,001 & 111 & ,150 \\
\hline Task Culture & &,- 222 & 101 &,- 106 & $-2,198$ & ,028 &,- 224 &,- 100 \\
\hline $\mathrm{R}=0,426$ & $\mathrm{R}^{2}=0,182$ & & & & & & & \\
\hline$F_{(4-435)}=26,428$ & $\mathrm{p}=, 000$ & & & & & & & \\
\hline
\end{tabular}

According to the standardized regression coefficients, the relative importance order of predictive variables on the level of meaninglessness of alienation to work is success culture $(\beta=-0,262)$, bureaucratic culture $(\beta=0,144)$, support culture $(\beta=-0,105)$, task culture $(\beta=-0,101)$. While success, support and duty culture reduces the level of meaninglessness, bureaucratic culture increases the level of meaninglessness. According to the results of the regression analysis, the regression equation predicting meaninglessness is as follows:

Meaninglessness $=(0,408 x$ Success Culture $)+(0,222 x$ Task Culture $)+(0,197 x$ Bureaucratic Culture $)+$ (0,128xSupport Culture)

\section{Predicting the Isolation Dimension by Sub-Dimensions of School Culture}

As a result of the multiple linear regression analysis, to show how the school culture predicts teachers' alienation to work, the sub-dimensions of school culture support and bureaucratic culture together have meaningful effect on isolation which is the sub-dimension of work alienation. There are meaningful relationship between the variables $\left(R=0,485, R^{2}=0.235\right),(F(4-476)=36,53, p<0,00)$. Together, these two variables explain $23 \%$ of the change in the level of alienation to work.

Table 5. Predicting the isolation dimension by sub-dimensions of school culture

\begin{tabular}{|c|c|c|c|c|c|c|c|c|}
\hline $\begin{array}{l}\text { Independent } \\
\text { Variables }\end{array}$ & Dependent Variable & B & $\begin{array}{c}\text { Standart } \\
\text { Error }\end{array}$ & $\beta$ & $\mathbf{t}$ & p & $\begin{array}{c}\text { Binary } \\
\mathbf{r}\end{array}$ & $\begin{array}{c}\text { Partial } \\
\quad \mathbf{r}\end{array}$ \\
\hline Constant & & 30,761 & 2,357 & & 13,049 & ,000 & & \\
\hline Support Culture & &,- 394 & ,087 &,- 340 & $-4,525$ & , 000 &,- 467 &,- 203 \\
\hline Success Culture & Isolation &,- 200 & 111 & -135 & $-1,810$ & ,071 &,- 432 &,- 083 \\
\hline \multicolumn{9}{|l|}{ Bureaucratic } \\
\hline Culture & & ,148 & ,055 & 114 & 2,718 & , 007 & ,104 & ,124 \\
\hline Task Culture & &,- 058 & ,093 &,- 029 &,- 625 & ,532 &,- 202 &,- 029 \\
\hline $\mathrm{R}=0,485$ & $R^{2}=0,235$ & & & & & & & \\
\hline$F_{(4-435)}=36,535$ & $\mathrm{p}=, 000$ & & & & & & & \\
\hline
\end{tabular}


According to the standardized regression coefficients, the relative importance order of predictive variables on the level of weakness of alienation to work, support culture $(\beta=-0,340)$, success culture $(\beta=-$ $0,135)$, bureaucratic culture $(\beta=0,114)$ and task culture $(\beta=-0,029)$. While support, success and duty culture decrease the level of isolation, bureaucratic culture increases the level of isolation. According to the results of the regression analysis, the regression equation predicting weakness is as follows:

Isolation $=(0,394 \times$ Support Culture $)+(0,148 \times B$ ureaucratic Culture $)$

\section{Predicting the Alienation to School Dimension by Sub-Dimensions of School Culture}

As a result of the multiple linear regression analysis, to show how the school culture predicts teachers' alienation to work, the sub-dimensions of school culture task and bureaucratic culture together have meaningful effect on alienation to school which is the sub-dimension of work alienation. There are meaningful relationship between the variables $\left(R=0,303, R^{2}=0.092\right),\left(F_{(4-476)}=12,02, p<0,00\right)$. Together, these two variables explain $9 \%$ of the change in the level of alienation to work.

Table 6. Predicting the alienation to school dimension by sub-dimensions of school culture

\begin{tabular}{|c|c|c|c|c|c|c|c|c|}
\hline $\begin{array}{l}\text { Independent } \\
\text { Variables }\end{array}$ & Dependent Variable & B & $\begin{array}{c}\text { Standart } \\
\text { Error }\end{array}$ & $\beta$ & $\mathbf{t}$ & $\mathrm{p}$ & $\begin{array}{c}\text { Binary } \\
\mathbf{r}\end{array}$ & $\begin{array}{c}\text { Partial } \\
\text { r }\end{array}$ \\
\hline Constant & & 16,847 & 1,779 & & 9,472 & ,000 & & \\
\hline Support Culture & &,- 016 & ,066 &,- 020 &,- 247 & ,805 & 174 &,- 011 \\
\hline Success Culture & Alienation to & 105 & ,083 & 102 & 1,253 & 211 & 189 & ,057 \\
\hline \multicolumn{9}{|l|}{ Bureaucratic } \\
\hline Culture & &,- 137 & ,041 &,- 152 & $-3,331$ & ,001 &,- 084 &,- 151 \\
\hline Task Culture & & ,350 & ,070 & ,254 & 4,998 &, 000 & 249 & ,223 \\
\hline
\end{tabular}

$\mathrm{R}=0,303 \quad \mathrm{R}^{2}=0,092$

$\mathrm{F}(4-435)=12,028 \quad \mathrm{p}=, 000$

According to the standardized regression coefficients, the relative importance order of predictive variables on the level of alienation from work to school alienation, task culture $(\beta=-0,254)$, bureaucratic culture $(\beta=0,152)$, success culture $(\beta=-0,102)$ and support culture $(\beta=-0.020)$. The bureaucratic and support culture reduces the level of alienation to school, while the culture of duty and success increases the level of alienation to school. According to the results of the regression analysis, the regression equation predicting weakness is as follows:

Alienation to School $=(0,350 \times$ Task Culture $)+(0,137 \times$ Bureaucratic Culture $)$

\section{Result and Discussion}

According to the findings obtained as a result of the research, school culture significantly predicts teachers' level of alienation to work. Success, support and task culture, which are the sub-dimensions of school culture, decrease the meaninglessness dimension of alienation to work, while bureaucratic culture increases the dimension of meaninglessness. The task culture increases alienation to school, while bureaucratic culture reduces alienation to school. The culture of support decreases the weakness and isolation of alienation, while increasing the culture of duty. The culture of success also reduces the weakness dimension of alienation to work. According to the research findings, the bureaucratic culture and the culture of duty, support and success 
significantly predict alienation to work. Korkmaz and Çevik (2017) state that organizational culture is a meaningful predictor of alienation to work. Similarly, Demirez and Tosunoğlu (2017) found out that there is a moderately negative relationship between organizational climate and culture and alienation to work, and the fact that the organizational climate is positive and the perception of the culture of the organization is stronger. Özdevecioğlu and Akın (2013) state that organizational culture has a significant effect on alienation. According to Sezgin (2010), school culture affects the organizational commitment level of teachers and the culture of task is more dominant in schools. According to the results of the research, increasing the culture of task in schools decreases alienation to work. Hongboontri and Keawkhong (2014) emphasized that the reason for this is that the working culture in schools deeply affects teachers' beliefs about schools and their teaching practices and teaching behavior patterns. According to Gaziel and Weiss (1990), alienation to work in organizations results from bureaucratic structures, and rules and policies that limit the participation of individuals in the decision cause alienation to the job. Finally, Aytaç (2005), inferred that organizations with a modern bureaucracy have a strict functioning and as a result, alienation occurs when individuals feel pressure on them. According to the results of the research, the fact that bureaucratic culture is a significant predictor of the weakness, meaninglessness and isolation dimension of alienation to work is the determinant that school culture may cause the teacher to break or connect with the teaching work at his school.

According to another result of the research, it was concluded that perceptions of school alienation and weakness dimensions are higher than meaninglessness and isolation. In this context, Elma (2003) revealed that the dimensions of teachers' perception of alienation to work are the dimensions of alienation and weakness in school. Yilmaz and Sarpkaya (2009) stated that teachers experience consecutively weakness, isolation and alienation to school; and there is a significant relationship between the bureaucratic structure of the school and weakness, and teachers with more than 25 years of experience encounter with alienation less. DeRose (1985) also stated that the dimensions of isolation and weakness are the most common form of alienation that teachers experience, and that there is a relationship between the power applied by school administrators and alienation. According to Ömeroğlu (2006), teachers' attitudes towards school differ significantly compared to bureaucracy. The bureaucracy implemented by school administrators increases teachers' alienation to work. Akpolat and Oğuz (2015) emphasized that alienation to work is felt mostly by teachers in the dimension of weakness. According to Erjem (2005), teachers feel more alienated in the sub-dimension of weakness, and the dimensions where teachers' perceptions of alienation to work are the lowest point of meaninglessness and isolation. Tsang (2018) emphasized that teachers 'alienation has correlated with the organizational variables including bureaucracy culture and their roles arising from teachers' jobs. According to Atay and Gerçek (2017), as a result of loading different roles to individuals, the individual goes away from work by having meaning confusion and these role ambiguities increase alienation to work. It is thought that the social, organizational and educational roles of teachers have become increasingly complex as a result of the rapid complexity of both the social functions and organizational structures of schools in recent years, and therefore uncertainty of teachers' role in schools is explained by this way.

As a result of the research, it was concluded that there is a significant relationship between teachers' alienation levels and school culture. Kahveci and Demirtaş (2014) concluded that organizational culture negatively affects organizational alienation. The strong culture in organizations increases the sense of safety and loyalty of employees. According to Aiken and Hage (1966), central and official organizations cause alienation to jobs in educational context. The fact that schools' formal and decentralized structures can be stated as a reason for teachers' alienation to work. Dariyemez (2010) stated that there is alienation due to the fact that the organizational culture cannot be transferred to the teachers well. Terzi (2005) stated that taskoriented school culture is more common and success, bureaucratic and supporting culture come. According to Güçlü (2003), bureaucratic culture is more dominant in the Turkish public schools. According to the results of the research, bureaucratic culture prevails in schools and this increases the level of alienation. The work of 
Terzi and Güçlü supports the conclusion that the culture of task and success reduces the level of meaninglessness, weakness and isolation of alienation to work. These studies support the conclusion that the school culture reached as a result of the research predicts alienation to work. As a result, it is possible to state that teachers experience alienation against their work within the school organization. When the relationship of this alienation with school culture is examined, differences are observed in the context of the subdimensions of alienation to work. Bureaucratic culture and school culture dimensions predict the subdimensions of alienation to work. According to this, as bureaucracy increases in schools, individuals in the organization become more alienated from their jobs. In addition, the culture of success and support reduces alienation from work, as opposed to bureaucratic culture.

Teachers' participation in the decision, autonomous work environments, fulfilling the roles imposed, and self-esteem of the teacher also affect their alienation (Brandon, Wang \& Hang, 1994). According to Mercan (2006), alienation prevents teachers' efficiency in teaching, working in harmony with school administrators and other teachers, contributing to social development, developing themselves professionally, being an example to society and students, and creativity. For this reason, it is unexpected that a teacher who is alienated from his job will be useful both for himself and for the society he/she is in. In addition, Rosenblum and Firestone (1987) stated that the characteristics of the school are more effective than environmental factors in alienation. Studies should be carried out in order to realize the aims of education, to ensure the happiness of every individual in the society and to reduce the alienation experienced by teachers at school. It is thought that teachers' alienation to work can be prevented by improving school conditions, reducing the bureaucratic culture in schools and creating a moderate school climate. 


\section{REFERENCES}

Aiken, M., \& Hage, J. (1966). Organizational alienation: A comparative analysis. American Sociological Review, 31(4), 497-507, doi:10.2307/2090773.

Akpolat, T., \& Oğuz, E. (2015). İlkokul ve ortaokul öğretmenlerinde örgütsel sinizmin işe yabancılaşma düzeyine etkisi. Mersin Üniversitesi Ĕ̆itim Fakültesi Dergisi, 11(3), 947-971, doi: 10.17860/efd.81842.

Atay, S. E., \& Gerçek, M. (2017). Algılanan rol belirsizliğinin işe yabancılaşma üzerindeki etkisinin ve demografik değişkenlere göre farklılıklarının incelenmesi. Ordu Üniversitesi Sosyal Bilimler Araştırmaları Dergisi, 7(2), 321-332.

Aydın, M. (2013). Örgütsel kültür ve örgütsel iklim. M. Aydın içinde, Örgütsel Davranış (s. 51-68). Ankara: Gazi Kitabevi.

Aytaç, Ö. (2005). Modern bürokrasiler ve yabancılaşma ethosu. Fırat Üniversitesi Sosyal Bilimler Dergisi, 15(2), 319-348.

Bakioğlu, A. (1996). Öğretmenlerin kariyer evreleri (Türkiye'de resmi lise öğretmenleri üzerine yapılan bir araştırma). II. Ulusal Eğitim Sempozyumu. İstanbul: M. Ü. Atatürk Eğitim Fakültesi Yayınları.

Başaran, İ. E. (1998). Yönetimde insan ilişkileri: Yönetsel davranış. Ankara: Nobel Akademi Yayıncılık.

Blauner, R. (1964). Alienation and freedom: The factory worker and his industry. The University of Chicago Press, 6(1), 83-85.

Brandon, P. R., Wang, Z., \& Heck, R. H. (1994). Teacher involvement in school-conducted needs assessments: Issues of decision-making process and validity. Evaluation Review, 18(4), 458471. https://doi.org/10.1177/0193841X9401800405.

Brown, K. M., \& Wynn, S. R. (2009). Finding, supporting and keeping: The role of the principal in teacher retention issues. Leadership $\mathcal{E}$ Policy in Schools, 8, 37-63.

Büyüköztürk, Ş., Çokluk, Ö., \& Köklü, N. (2015). Sosyal bilimler için istatistik. Ankara: Pegem Akademi.

Büyüköztürk, Ş., Kılıç Çakmak, E., Akgün, Ö. E., Karadeniz, Ş., \& Demirel, F. (2014). Bilimsel araştırma yöntemleri. Ankara: Pegem Akademi.

Can, A. (2018). SPSS ile bilimsel araştırma sürecinde nicel veri analizi. Ankara: Pegem Akademi.

Cha, S. H., \& Cohen-Vogel, L. (2011). Why they quit: A focused look at teachers who leave for other occupations. School Effectiveness and School Improvement, 22(4), 371-392.

Darıyemez, K. (2010). Örgütlerde ortaya çıkan yabancılaşma sorunu ve bu sorunun çözümü açısından halkla ilişkiler çalışmalarının önemi (Başkent Üniversitesi Ankara Hastanesi Örneği). (Unpublished master thesis). (Access No.264765).

Demirez, F., \& Tosunoğlu, N. (2017). Örgüt ikliminin işe yabancılaşma üzerine etkisi: Gazi Üniversitesi Rektörlüğünde bir araştırma. İşletme Araştırmaları Dergisi, 9(2), 69-88, doi: 10.20491/isarder.2017.262.

DeRose, M. N. (1985). A study of the relationship between perceived power use by secondary school principals and degree of teachers alienation in school situations perceived by their principals as stressful. Dissertation Abstracts International, 46(6).

Doğan, S. (2017). Okul kültürü ve iklimi. C. T. Uğurlu içinde, Okul yönetimi (s. 91-119). Ankara: Anı Yayıncılık.

Elma, C. (2003). İlköğretim okulu öğretmenlerinin işe yabancılaşması (Ankara ili örneği). (Unpublished doctoral thesis Tezi). (Access No.205179). 
Erjem, Y. (2005). Eğitimde yabancilaşma olgusu ve öğretmen: Lise öğretmenleri üzerine sosyolojik bir araştırma. Türk Ĕ̆itim Bilimleri Dergisi, 3(4), 395-417.

Farber, K. (2015). Why great teachers quit and how we might stop the exodus. New York: Skyhorse Publishing.

Feuer, L. (2019, Ağustos 5). What is alienation? The career of a concept. İstanbul, Türkiye.

Frolov, İ. (1991). Felsefe sözlü̈̆̈̈̈. Cem Yayınevi.

Gaziel, H. H., \& Weiss, I. (1990). School bureaucratic structure, locus of control and alienation among primary school teachers. Research in Education, 44(1), 55-66, https://doi.org/10.1177/003452379004400105.

Güçlü, N. (2003). Örgüt kültürü. Gazi Üniversitesi Sosyal Bilimler Dergisi, 23(2), 61-85.

Hanushek, E. A., Kain, J. F., \& Rivkin, S. G. (2004). Why public schools lose teachers? Journal of Human Resources, 39, 326-354.

Hongboontri, C., \& Keawkhong, N. (2014). School culture: Teachers' beliefs, behaviors, and instructional practices. Australian Journal of Teacher Education, 39(5),66-88.

Ingersoll, R. M. (2001). Teacher turnover and teacher shortages: An organizational analysis. American Educational Research Journal, 38(3), 499-534.

Isherwood, G. B., \& Hoy, W. K. (1973). Bureaucracy, powerlessness and teacher work values. The Journal of Educational Administration, 11(1), 124-138.

İnand1, Y., Tunç, B., \& Kılavuz, T. (2018). Women's career barriers and professional alienation: The teachers' case in Turkey. International Online Journal of Educational Sciences, 10(3), 133-146, https://doi.org/10.15345/iojes.2018.03.010.

İstanbul İl Milli Eğitim Müdürlüğü. (2019, Ekim 10). İstanbul İl MEM istatistikleri. chromeextension://oemmndcbldboiebfnladdacbdfmadadm/https://istanbul.meb.gov.tr/meb_iys_dosyalar/201 7_04/12163411_2016-2017_Ystatistik_KitabY_Taslak.pdf.

Kahveci, G., \& Demirtaş, Z. (2014). Örgüt kültürünün örgütsel yabancılaşmaya etkisi örgütsel güvenin aracılık rolü. Turkish Journal of Educational Studies, 1(3), 27-62.

Karcioğlu, F. (2001). Örgüt kültürü ve örgüt iklimi ilişkisi. İktisadi ve İdari Bilimler Dergisi, 15, 265-283.

Kiraz, S. (2011). Yabancılaşmanın kökeni üstüne. Felsefe ve Sosyal Bilimler Dergisi, 12, 147-169.

Korkmaz, M., \& Çevik, M. S. (2017). Analysis of the relation between organizational culture and alienation in secondary educational institutions. Educational Administration: Theory and Practice, 23(4), 675-716.

Lankford, H., Loeb, S., \& Wyckoff, J. (2002). Teacher sorting and the plight of urban schools: A descriptive analysis. Educational Evaluation and Policy Analysis, 24, 37-62.

Levin, W. C. (1989). Sociological ideas: Concepts and applications. Wadsworth.

Marshall, G. (1999). Sosyoloji sözlüğ̈̈̈. Ankara: Bilim ve Sanat Yayınları.

McMillan, J. H., \& S. S. (2010). Research in education: Evidence-Based inquiry. Boston: Pearson.

MEB. (2018). 2018 Yılı Faaliyet Raporu. Milli Eğitim Bakanlığı. https://sgb.meb.gov.tr/www/quotmeb-2018-yiliidare-faaliyet-raporuquot-yayinlanmistir/icerik/343

Mercan, M. (2006). Öğretmenlerde örgütsel bağhllı örgütsel yabancllaşma ve örgütsel vatandaşlık. (Unpublished master thesis). (Access No.187444). 
Mont, D., \& Rees, D. I. (1996). The influence of classroom characteristics on high school teacher turnover. Economic Inquiry, 34, 152-167.

Mottaz, C. J. (1981). Some determinants of work alienation. The Sociological Quarterly, 22(4), 515-529.

Neuman, W. L. (2006). Toplumsal araştırma yöntemleri: Nitrel ve nicel yaklaşımlar. Ankara: Yayın Odası.

Ömeroğlu, Ö. (2006). Okul yönetiminde bürokrasi ile öğretmenlerin okula ilişkin tutumları arasındaki ilişki. (Unpublished master thesis). (Erişim No.205958).

Özdevecioğlu, M. ve Akın, M. (2013). Yöneticilerin örgüt kültürü ve örgütler arası vatandaşlık davranışları algıları. Çankırı Karatekin Üniversitesi İktisadi ve İdari Bilimler Fakültesi Dergisi, 3(2), 112-131.

Özer, S., \& Güllüce, A. Ç. (2019). Örgütsel sinizm ve işe yabancılaşma ilişkisi ve etkisi: TRB1 bölgesi otel işgörenleri üzerinde bir araştırma. Anemon Muş Alparslan Üniversitesi Sosyal Bilimler Dergisi, 7(1), 37-47, http://dx.doi.org/10.18506/anemon.408477.

Özler, N. D., \& Dirican, M. Ö. (2014). Örgütlerde yabancılaşma ile tükenmişlik sendromu arasındaki ilişkiyi belirlemeye yönelik bir araştırma. Dumlupınar Üniversitesi Sosyal Bilimler Dergisi, 39, 291-310.

Payne, D. E. (1974). Alienation: An organizational-societal comparison. Social Forces, 53(2), 274-282, doi: $10.2307 / 2576020$

Pugh, K. J., \& Zhao, Y. (2003). Stories of teacher alienation: A look at the unintended consequences of efforts to empower teachers. Teaching and Teacher Education, 19(2), 187-201.

Rosenblum, S., \& Firestone, W. A. (1987). Alienation and commitment of high school students and teachers, ERIC, 1-39.

Schein, E. H. (2010). Organizational culture and leadership (fourth edition). United States of America: Jossey Bass.

Seeman, M. (1959). On the meaning of alienation. American Sociological Review, 24(6), 783-791.

Sezgin, F. (2010). Öğretmenlerin örgütsel bağlılığının bir yordayıcısı olarak okul kültürü. Ĕ̆itim ve Bilim, 35(156), 142-159.

Şimşek, H., Balay, R., \& Şimşek, A. S. (2012). İlköğretim sınıf öğretmenlerinde mesleki yabancılaşma. Ĕğitim Bilimleri Araştırmaları Dergisi, 2(1), 53-72.

Şişman, M. (1995). Örgüt kavramının kültürel açıdan çözümlenmesi ve eğitim örgütleri. Kuram ve Uygulamada Ĕ̆itim Yönetimi, 1(1), 79-94.

Şişman, M. (2002). Örgütler ve kültürler. Ankara: Pegem Akademi Yayıncılık.

Teber, S. (1990). Politik psikoloji notları. İstanbul: Ara Yayıncılık.

Terez, T. (2000). İş ve anlam. Executive Excellence, 4(41), 6-7.

Terzi, A. R. (2000). Örgüt kültürü. Ankara: Nobel Yayın Dağıtım.

Terzi, A. R. (2005). İlköğretim okullarında örgüt kültürü. Kuram ve Uygulamada Ĕ̆itim Yönetimi, 11(3), 423-442.

Tezcan, M. (1985). Gençlik ve yabancılaşma. Ankara Üniversitesi Eğitim Bilimleri Fakültesi Dergisi, 1(18), $121-127$.

Texas Center for Education Research. (2002). The cost of teacher turnover. Austin, TX: TexasState Board for Educator Certification.

Tsang, K. K. (2018). Teacher alienation in Hong Kong. Discourse: Studies in the Cultural Politics of Education, $39(3), 335-346$. 
Turgut, T., \& Kalafatoğlu, Y. (2016). İşe yabancılaşma ve örgütsel adalet. İş, Güç Endüstri İlişkileri ve İnsan Kaynakları Dergisi, 18(1), 23-46.

Tye, B. B., \& O'brien, L. (2002). Why are experienced teachers leaving the profession? Phi Delta Kappan, 84(1), 24-32.

Yapıcı, M. (2004). Eğitim ve yabancılaşma. Uluslararası İnsan Bilimleri Dergisi, 1(1), 1-9.

Yıldırım, A. (2013). Ziya Gökalp'te toplumsal değişme: "Kültür-Uygarlık" Tezi. Mehmet Akif Ersoy Üniversitesi Sosyal Bilimler Enstitüsü Dergisi, 5(9), 1-20.

Yılmaz, S., \& Sarpkaya, P. (2009). Eğitim örgütlerinde yabancılaşma ve yönetimi. Uluslararası İnsan Bilimleri Dergisi, 6(2), 314-333.

Yorulmaz, Y. I., Altınkurt, Y., \& Yılmaz, K. (2015). The relationship between teachers' occupational professionalismand organizational alienation. Educational Process: International Journal, 4(1-2), 31-44.

Yüksel, H. (2014). Yabancılaşma kavramı paralelinde emeğin yabancılaşması ve sonuçları. AİBÜ Sosyal Bilimler Enstitüsü Dergisi, 159-188.

Zielinski, A. E., \& Hoy, W. K. (1983). Isolation and alienation in elementary schools. Educational Administration Quarterly, 19(2), 27-45, https://doi.org/10.1177/0013161X83019002003. 